\title{
Study of Agronomical and Technological Quality Characteristics of Some Special Egyptian Rice Varieties
}

\author{
Shimaa A. Badawy and S. A. Mahgoub ${ }^{* \#}$ \\ Agronomy Department, Faculty of Agriculture, Kafrelsheikh \\ University, Kafrelsheikh and ${ }^{*}$ Crops Technology Research \\ Department, Food Technology Research Institute, Agricultural \\ Research Center, Cairo, Egypt.
}

\begin{abstract}
7 HIS STUDY aimed to evaluate the agronomic and technological 1 quality characteristics of Jasmine, Waxy and Black rice varieties under Egyptian conditions during seasons 2012-2013 compared to traditional one. Jasmine rice variety out yielded other varieties and gave the highest values for yield and yield component characters. Black rice had the smallest values for yield and yield component followed by Sakha 106 characters except panicle weight which recorded the second value with both Waxy and Sahkha 106. Jasmine rice characterized by low $\%$ broken and \% paddy which related to reduced grain loss. Black rice had higher antioxidant activity (70.52\% DPPH). In addition, its high nutritional value relates to its chemical and mineral contents, jasmine rice recorded the highest numerical value for most parameters and the lowest cooking time 9.33 min, husk ranged from 20.8 to $24.4 \%$ in the studied varieties while milled rice ranged $65.5-68.5 \%$ in varieties. Waxy rice had the highest 1000 kernels weight $(22.7 \mathrm{gm})$, the physical parameters $(0.83 \mathrm{~g} / \mathrm{ml})$, $5.34 \%$ amylose and the highest gel consistency $95.1 \mathrm{~mm}$. Black rice recorded the highest protein content $(8.69 \%)$ and minerals; 1874.8 (mg cy-3-glc/100g db) anthocynins; 716.4 (mg/GAE/100g) total phenols; 187.4 (mg quarstine/100g DW) flavonoids.
\end{abstract}

Keywords: Rice varieties, Physical properties, Chemical composition, Minerals, Anthcyanins, Total phenol, Flavonoids, Cooking quality.

Rice is a major cereal crop in the developing world and an important stable food source for over half of the world population. Although widely consumed as white rice, there are many special cultivars of rice that contain color pigments, such as Black rice and red rice (Sompong et al., 2011). Egypt is the largest producer of rice in Africa, with supplying 5.9 million tons of rice in 2013 (more than $22 \%$ of rice production in Africa). The quality of milled parboiled rice is being assessed based on physical parameters like degree of milling ، percentage head rice, broken grain, chalkiness, red streak grain, grain size, color, and shape 1000 grains weight (Abdelhady et al., 2014).

${ }^{\#}$ Corresponding author: S.A. Mahgoub, e-mail: saadk125@yahoo.com 
Generally, rice is consumed as a whole kernel of white rice obtained by milling (dehulling and polishing) rough rice. The degree of milling depends on purposes of milling required. Therefore, degree of milling is one of the key factors affecting several aspects of rice quality such as nutritional, chemical, physicochemical, cooking, and eating quality. Also, the degree of milling brought about variations in nutrient contents (Mahajan \& Kaur, 2014).

The distinct divergence in waxy rice is in the gelatinization temperature. Waxy rice can be divided into a high and a low gelatinization temperature group. High- gelatinization temperature waxy rice is harder after cooking and show accelerated staling compared to low- gelatinization temperature rice, but significant differences are also observed among some low gelatinization temperature pairs. In many food applications, waxy rice is preferred to non waxy rice due to its starch physiochemical properties. The economic value of rice depends on its cooking and processing quality, which can be measured in terms of water uptake ratio, grain elongation during cooking, solids in cooking water and cooking time. Rice varieties with amylose content of more than $25 \%$ absorb more water and have afluffy texture after cooking (Thomas et al., 2013).

The physicochemical characteristics include grain length (L), grain breadth (B), $\mathrm{L} / \mathrm{B}$ ratio, hulling and milling percentage. The cooking qualities are amylose content, alkali spreading value, water uptake, volume expansion ratio and kernel elongation ratio. Grain quality is a very wide area encompassing diverse characters that are directly or indirectly related to exhibit one quality type (Siddiqui et al., 2007). It also has been reported that a diet containing Black rice extracts which had anthocyanin $(31.3 \mathrm{~g} / 100 \mathrm{~g})$ decreased cholesterol, LDL- cholesterol and concentration of triacylglycerol in plasma of rats (Yodmanee et al., 2011).

The aimed of the present study is to evaluate quality characteristics (agronomic ,physical, chemical, and cooking) of the new rice grain varieties cultivated in Egypt in compared to conventionally one (Sakha 106).

\section{Materials and Methods}

Experiments were laid out in a completely randomized design with three replications. Rice varieties under these studies are (Sakha 106, Waxy, Jasmine and Black rice). Were obtained from research component of seed productionRice Research Department, Field Crop Research Institute, ARC, Giza, Egypt. Agronomic characters yield and its components were recorded from the experimental plots during two rice growing seasons 2012 and 2013 at Sakha research station, agronomic practices were carried out as recommended.

Preparation of rice samples for technological, eating, cooking quality and chemical studies conducted at Crops Technology Research Department, Food Technology Research Institute, Agricultural Research Center, Egypt. Raw rice samples were dehulled by sataky machine and kept in polyethylene bags and stored in freezer at $-18^{\circ} \mathrm{C}$ until further analysis.

Egypt. J. Agron. 37, No. 1 (2015) 


\section{Determination of milling characteristics}

Husk, milling output and head rice percentage were estimated according to the method of Adair (1952).

\section{Determination of physical properties}

The kernel physical attributes (1000 kernel weight, kernel length, breadth and kernel length to breadth ratio) were measured according to Dorsey-Redding et al.(1991). Grain size and shape (FAO, 1975). Amounts of immature, mouldy, discolored, red rice, paddy, chalky grains and stones (Warda, 1995), level of broken rice (Adu-Kwarteng et al., 2003) and bulk density (Singh et al., 2005).

\section{Determination of chemical composition}

Proximate analysis including moisture, protein, lipid, ash and crude fiber were carried out according to the methods of AOAC (2005). Carbohydrates content was calculated by difference.

\section{Determination of minerals}

Magnesium, sodium, potassium, manganese, iron, calcium and zinc were determined according to AOAC (2005). Perkin Elmer (Model 3300, USA) Atomic Absorption Spectrophotometer was used to determine these minerals.

\section{Energy value}

The energy value for tested varieties was calculated from the following equation as reported by Hawk et al. (1949), Energy value $=4$ ( $\mathrm{g}$ protein $+\mathrm{g}$ carbohydrates) +9 (g fat).

\section{Determination of antioxidants}

Total anthocyanin pigment content of the rice samples was determined, according to the modified $\mathrm{pH}$ differential methods of Giusti \& Wrolstad (2005) and Hosseinian et al. (2008). Total phenols were estimated by the FolinCiocalteu method reported in Elfalleh et al. (2009). The amount of total flavonoids was measured spectrophotometrically by the method of Nasri et al. (2011). The DPPH (2,2 diphenyl-1- picric hydrazyl) radical scavenging activity of methanolic extracts was determined according the method reported by Okonogi et al. (2007).

\section{Determination of cooking quality}

Amylose content determined by according to the method of Juliano et al. (1981). Cooking time was determined as described by Batcher et al. (1956). Water uptake ratio and gruel solid loss as described by Singh et al. (2003). Elongation ratio and volume expansion ratio as described by Singh et al. (2005). Gelatinization temperature (GT) was determined according to the method described by Bhattacharya (1979). Gel consistency (GC) was determined according to the method described by Little (1958). 
Statistical analysis

The obtained data from chemical, physical and sensory evaluation were exposed to analysis of variance. Duncan's multiple range tests at $(P \leq 0.05)$ level was used to compare between means.

\section{Results and Discussion}

\section{Yield and its components}

Data in Table 1 show that highly significant differences were found among the tested varieties (Sakha 106, Jasmine, Waxy and Black) for all the studied parameters. Whereas, Jasmine rice variety recorded the highest numerical value for all the studied parameters except for 1000 grain weight which recorded the second value after both Sakah 106 and Black rice with no significant differences between them. On the other hand, Black rice recorded the smallest numerical values among all the other studied parameters except panicle weight which recorded the second numerical value with both Waxy and Sakha 106 and Jasmine variety which recorded the highest panicle weight.

Our results are in parallel with the observation by Sadhukhan \& Chattopadhyay (2000) who stated that aromatic rice had more number of grains per panicle and small grain size than basmati types. Yield and nutritional value are mostly determined by the synthesis and storage of carbohydrates, proteins and minerals during grain filling, and culinary quality is affected by the interaction of various enzymes to produce the final structure of the starch at the molecular and granule levels.

TABLE 1. Combined analysis of yield and its components of some Egyptian rice varieties.

\begin{tabular}{|l|l|l|l|l|}
\hline \multirow{2}{*}{ Parameters } & \multicolumn{4}{|c|}{ Rice varieties } \\
\cline { 2 - 5 } & Sakha106 & Jasmine & Waxy & Black \\
\hline Total duration (days) & $126.6^{\mathrm{c}}$ & $147^{\mathrm{a}}$ & $136^{\mathrm{b}}$ & $120.6^{\mathrm{d}}$ \\
\hline Plant height (cm) & $101.87^{\mathrm{b}}$ & $110.5^{\mathrm{a}}$ & $95.13^{\mathrm{c}}$ & $90.53^{\mathrm{d}}$ \\
\hline No. of tillers /panicle & $23.33^{\mathrm{b}}$ & $25.33^{\mathrm{a}}$ & $18.66^{\mathrm{c}}$ & $13.33^{\mathrm{d}}$ \\
\hline No. of panicle /plant & $19.33^{\mathrm{b}}$ & $21.35^{\mathrm{a}}$ & $16.33^{\mathrm{c}}$ & $9.33^{\mathrm{d}}$ \\
\hline Panicle weight (g) & $3.59^{\mathrm{b}}$ & $4.62^{\mathrm{a}}$ & $3.42^{\mathrm{b}}$ & $3.9^{\mathrm{b}}$ \\
\hline Panicle length (cm) & $22.7^{\mathrm{b}}$ & $25.83^{\mathrm{a}}$ & $19.96^{\mathrm{c}}$ & $18.66^{\mathrm{d}}$ \\
\hline 1000 grain weight (g) & $28.35^{\mathrm{a}}$ & $27.35^{\mathrm{b}}$ & $26.32^{\mathrm{c}}$ & $28.33^{\mathrm{a}}$ \\
\hline No. of grains /panicle & $131.33^{\mathrm{b}}$ & $151.30^{\mathrm{a}}$ & $126.69^{\mathrm{c}}$ & $107.66^{\mathrm{d}}$ \\
\hline Grain yield /plant & $43.64^{\mathrm{b}}$ & $46.82^{\mathrm{a}}$ & $38.79^{\mathrm{c}}$ & $23.92^{\mathrm{d}}$ \\
\hline
\end{tabular}

Means within a column with different letters are significantly different at $(\mathrm{P} \leq 0.05)$

\section{Milling quality characters}

The de-hulling of rice is one of the important postharvest processes. If the hulling percentage is high, then the recovery of rice is also increased. It could be Egypt. J. Agron. 37, No. 1 (2015) 
observed from Table 2 that Sakha 106 rice variety had the highest value of milled rice $71.4 \%$, while the waxy rice variety recorded the lowest $65.5 \%$. The result agreed with Rita \& Sarawgi (2008) who reported that the traditionally cultivated rice varieties, hulling percentage ranged from 63 to $81 \%$. On the other hand, the head rice is recorded the highest value of Jasmine rice $62.5 \%$, and the lowest value Black rice 55.6\%. Dipti et al. (2003) showed that the head rice recovery indicates that weight of whole grains after industrial processing. For quality evaluation, head rice recovery is one of the most important characters and more than $65 \%$ of head rice recovery is desirable. Head rice is the proportion of the intact grain in the milled rice. Head rice value ranged from 55.6-62.5\% in all the rice varieties.

TABLE 2. Milling characteristics tested of rice varieties.

\begin{tabular}{|l|c|c|c|c|}
\hline \multirow{2}{*}{$\begin{array}{l}\text { Parameters } \\
\text { g/100g }\end{array}$} & \multicolumn{4}{|c|}{ Rice varieties } \\
\cline { 2 - 5 } & Sakha106 & Jasmine & Waxy & Black \\
\hline Husk & $21.3^{\mathrm{c}}$ & $24.4^{\mathrm{a}}$ & $20.8^{\mathrm{d}}$ & $23.4^{\mathrm{b}}$ \\
\hline Milled rice & $71.4^{\mathrm{a}}$ & $68.5^{\mathrm{b}}$ & $65.5^{\mathrm{d}}$ & $66.5^{\mathrm{c}}$ \\
\hline Head rice & $61.5^{\mathrm{b}}$ & $62.5^{\mathrm{a}}$ & $56.6^{\mathrm{c}}$ & $55.6^{\mathrm{d}}$ \\
\hline
\end{tabular}

Means within a column with different letters are significantly different at $(\mathrm{P} \leq 0.05)$.

\section{Physical properties}

Physical properties of rice varieties were evaluated to provide important facts in determining their appropriate uses. Results of the 1000-kernel weight for different rice varieties analyzed in this study showed significant differences as shown in Table 3. Waxy rice had the highest 1000-kerneal weight $(22.7 \mathrm{~g})$ followed by Sakha106 (22.5 g), Black rice (21.4g) and Jasmine rice 18.4g. There were significant differences in the $\mathrm{L} / \mathrm{b}$ ratio for Sakha 106, Jasmine rice, Waxy rice and Black rice. Overall, highest $\mathrm{L} / \mathrm{b}$ ratio was recorded for the Jasmine rice $(3.77 \%)$ whereas, the lowest ratio was recorded for waxy rice $(1.31 \%)$. Size and shape are among the grain characteristics that indicate the market ability and commercial viability of rice these result agreed with Majzoobi \& Farahnaky (2008).

Therefore, local varieties can be marketed based on the size and shape preference of consumers. Diako et al. (2011) who reported that the analysis shape; ( $\mathrm{L} / \mathrm{b}$ ratio) was performed to determine the shape of individual rice grains. A length to breadth ratio of more than 3 is generally considered as slender (2.13.0: medium), (1.1-2.0: bold), (2.0 round). Size of (>7.0:extra-long);(6.0-6.99: long), (5.0-5.99: medium) and (<5.0: short). Determining the rice grain shape and width are highly essential as both, cooking and eating properties are strongly influenced by these parameters. In this study it was clear that grain shape of Sakha106 and Black rice is medium, Jasmine is slender, and Waxy is bold. On the other hand, the size of rice grain Sakha106 variety is long, Jasmine rice is extra long, waxy rice is medium and Black rice is long. The grain size and shape of most high yielding rice varieties is short to medium bold with translucent 
appearance (Banu et al., 1992). From the Table 3 it could be observed that significant differences of immature grains percentage the highest value in Sakha106 rice variety $(0.36 \%)$ and the lowest value in Jasmine rice $(0.17 \%)$, and not detected mouldy grains of rice verities. Physical examination showed more broken in the local varieties. The tolerance levels are for red rice, $4 \%$, for chalky grains, 6\%, and immature grains $2 \%$ according to Codex Alimentarius Commission (1990). In this study all the varieties examined were below the tolerance levels and, therefore, meet these quality criteria for market competitiveness.

TABLE 3. Physical measurements of some rice varieties.

\begin{tabular}{|l|c|c|c|c|}
\hline \multirow{2}{*}{ Parameters } & \multicolumn{4}{|c|}{ Rice varieties } \\
\cline { 2 - 5 } & Sakha106 & Jasmine & Waxy & Black \\
\hline 1000 kernel grain (gm) & $22.5^{\mathrm{a}}$ & $18.4^{\mathrm{c}}$ & $22.7^{\mathrm{a}}$ & $21.4^{\mathrm{b}}$ \\
\hline Length (mm) & $6.15^{\mathrm{b}}$ & $8.52^{\mathrm{a}}$ & $5.25^{\mathrm{c}}$ & $6.52^{\mathrm{b}}$ \\
\hline Breadth (mm) & $2.53^{\mathrm{b}}$ & $2.21^{\mathrm{c}}$ & $4.19^{\mathrm{a}}$ & $2.29^{\mathrm{c}}$ \\
\hline L/B ratio (\%) & 2.45 & 3.77 & 1.31 & 2.84 \\
\hline Grain size & Long & Extra long & Medium & Long \\
\hline Grain shape & Medium & Slender & Bol $^{\mathrm{d}}$ & Medium \\
\hline Immature (\%) & $0.36^{\mathrm{a}}$ & $0.17^{\mathrm{c}}$ & $0.26^{\mathrm{b}}$ & $0.18^{\mathrm{c}}$ \\
\hline Mouldy (\%) & $\mathrm{ND}$ & $\mathrm{ND}^{\mathrm{a}}$ & $\mathrm{ND}^{\mathrm{a}}$ & $\mathrm{ND}^{\mathrm{a}}$ \\
\hline Discolored (\%) & $0.24^{\mathrm{a}}$ & $0.15^{\mathrm{b}}$ & $0.13^{\mathrm{c}}$ & $0.17^{\mathrm{d}}$ \\
\hline Red rice (\%) & $0.14^{\mathrm{a}}$ & $0.0^{\mathrm{c}}$ & $0.09^{\mathrm{b}}$ & $0.0^{\mathrm{c}}$ \\
\hline Paddy (\%) & $0.35^{\mathrm{b}}$ & $0.27^{\mathrm{c}}$ & $0.47^{\mathrm{a}}$ & $0.22^{\mathrm{d}}$ \\
\hline Chalky grains (\%) & $0.92^{\mathrm{a}}$ & $0.75^{\mathrm{b}}$ & $0.28^{\mathrm{c}}$ & $0.18^{\mathrm{d}}$ \\
\hline Stones (\%) & $0.27^{\mathrm{b}}$ & $0.15^{\mathrm{d}}$ & $0.25^{\mathrm{c}}$ & $0.32^{\mathrm{a}}$ \\
\hline Broken (\%) & $5.62^{\mathrm{a}}$ & $3.32^{\mathrm{d}}$ & $3.57^{\mathrm{c}}$ & $4.73^{\mathrm{b}}$ \\
\hline Bulk density (g/ml) & $0.75^{\mathrm{c}}$ & $0.81^{\mathrm{a}} \mathrm{b}$ & $0.83^{\mathrm{a}}$ & $0.77^{\mathrm{bc}}$ \\
\hline
\end{tabular}

Source : (Diako et al., 2011).

Size : (>7.0 mm : extra long ; 6.0-6.99 mm : long; 5.0-5.99 mm : medium ; $<5.0 \mathrm{~mm}$ : short). Shape : (>3.0 mm: slender; 2.1-3.0 mm: medium; $1.1-2.0 \mathrm{~mm}:$ bold ; $=2.0 \mathrm{~mm}$ round). ND; not detectable

Means within a column with different letters are significantly different at $(\mathrm{P} \leq 0.05)$.

On the other hand, discolored of rice verities (Sakah106, Jasmine, Waxy and Black rice) to $(0.24,0.15,0.13$ and $0.17 \%)$, respectively. Also, red rice in Sakha106 rice variety $(0.14 \%)$, Waxy rice $(0.09 \%)$, Jasmine and Black was not detected for red grains, no significantly differences of results. The results in Table 3 clear that chalky grains in rice varieties (Sakha106 rice variety was the highest value $0.92 \%$ and the lowest value is Black rice $0.18 \%$ ).From the same table, no significant difference the stones in rice varieties, Sakha106 rice $(0.27 \%)$, Jasmine $(0.15 \%)$, Waxy $(0.25 \%)$ and Black rice $(0.32 \%)$. On the other hand, there is no significant no differences of broken rice (Sakha106, Jasmine, Waxy and Black rice).

Egypt. J. Agron. 37, No. 1 (2015) 
In high yielding rice varieties, the percentage of broken rice grains ranged from 3.34 to $5.32 \%$ the greater amount of chalkiness in the grain indicates that it is more prone to grain breakage during milling, which results in lower head rice recovery. Among the different varieties, bulk density was observed to be highest in Waxy rice $(0.83 \mathrm{~g} / \mathrm{ml})$, followed by Jasmine rice $(0.81 \mathrm{~g} / \mathrm{ml})$, Black rice $(0.77$ $\mathrm{g} / \mathrm{ml})$ and Sakha106 rice $(0.75 \mathrm{~g} / \mathrm{ml})$. These result agreed with Rachel et al. (2013) who reported that bulk density of rice varieties (white rice, brown rice, Jasmine rice and Black rice range 0.81-0.86 g/ml).

\section{Chemical properties}

Results in Table 4 shown significant differences in the proximal composition between different varieties of rice moisture content, which plays a significant role in determining the shelf-life (Rachel et al., 2013) was recorded to vary between 10.9-12.6 g/100g. Total protein content for all the rice varieties evaluated ranged from 5.66 to $8.69 \mathrm{~g} / 100 \mathrm{~g}$, the protein content was highest in Black rice $8.69 \mathrm{~g} / 100 \mathrm{~g}$ while as the lowest in Waxy rice $(5.66 \mathrm{~g} / 100 \mathrm{~g})$. Protein content was White rice $(5.96 \mathrm{~g} / 100 \mathrm{~g})$, Jasmine rice $(7.75 \mathrm{~g} / 100 \mathrm{~g})$ and Black rice $(8.16 \mathrm{~g} / 100 \mathrm{~g})$.

TABLE 4. Chemical composition of some rice varieties .

\begin{tabular}{|l|c|c|c|l|}
\hline \multirow{2}{*}{$\begin{array}{l}\text { Parameters } \\
\text { g/100g }\end{array}$} & \multicolumn{4}{|c|}{ Rice varieties } \\
\cline { 2 - 5 } & Sakha106 & Jasmine & Waxy & Black \\
\hline Moisture & $11.3^{\mathrm{b}}$ & $12.6^{\mathrm{a}}$ & $11.2^{\mathrm{bc}}$ & $10.9^{\mathrm{c}}$ \\
\hline Protein & $7.53^{\mathrm{b}}$ & $6.33^{\mathrm{c}}$ & $5.66^{\mathrm{d}}$ & $8.69^{\mathrm{a}}$ \\
\hline Fat & $1.47^{\mathrm{c}}$ & $0.89^{\mathrm{d}}$ & $1.62^{\mathrm{b}}$ & $1.84^{\mathrm{a}}$ \\
\hline Ash & $1.54^{\mathrm{a}}$ & $0.95^{\mathrm{c}}$ & $0.81^{\mathrm{d}}$ & $1.94^{\mathrm{b}}$ \\
\hline Crude fiber & $0.76^{\mathrm{c}}$ & $0.93^{\mathrm{c}}$ & $1.61^{\mathrm{b}}$ & $1.73^{\mathrm{a}}$ \\
\hline Carbohydrate & $77.4^{\mathrm{bc}}$ & $78.3^{\mathrm{a}}$ & $79.1^{\mathrm{ab}}$ & $74.9^{\mathrm{c}}$ \\
\hline
\end{tabular}

Means within a column with different letters are significantly different at $(\mathrm{P} \leq 0.05)$.

While fat content ranged from 0.89 to $1.84 \mathrm{~g} / 100 \mathrm{~g}$. Overall, highest fat content was recorded in Black rice variety $(1.84 \mathrm{~g} / 100 \mathrm{~g})$, while lowest fat content was recorded in Jasmine rice variety $(0.89 \mathrm{~g} / 100 \mathrm{~g})$. These results were similar with Osman \& Abd El-Galeel (2008) who reported that fat content was in white rice $(0.66 \mathrm{~g} / 100 \mathrm{~g})$, Jasmine rice $(0.65 \mathrm{~g} / 100 \mathrm{~g})$, Waxy rice $(0.60 \mathrm{~g} / 100 \mathrm{~g})$ and Black rice $(1.93 \mathrm{~g} / 100 \mathrm{~g})$. Also, the ash content high in Black rice $(1.94 \mathrm{~g} / 100 \mathrm{~g})$ and low in Waxy rice $(0.81 \mathrm{~g} / 100 \mathrm{~g})$. There are a significant differences recorded for crude fiber content White, Jasmine, Waxy and Black rice varieties. The values of crude fiber were ranged from 0.76 to $1.73 \mathrm{~g} / 100 \mathrm{~g}$. Black rice is also known to be a good source of fiber and it was the highest in this study. Carbohydrate content was high in all varieties $(>70 \mathrm{~g} / 100 \mathrm{~g})$ and hence can be considered to be a good source of carbohydrate. The Waxy rice contained the highest amount of carbohydrates $(79.1 \mathrm{~g} / 100 \mathrm{~g})$, while the Black rice contained the lowest amount of carbohydrates $(74.9 \mathrm{~g} / 100 \mathrm{~g})$ these result agreed with Rachel et al. (2013) who showed that the carbohydrates content in White rice $(80.14 \mathrm{~g} / 100 \mathrm{~g})$, Jasmine rice $(79.34 \mathrm{~g} / 100 \mathrm{~g})$ and Black rice $(78.26 \mathrm{~g} / 100 \mathrm{~g})$. 
Energy value

Energy value in Fig. 1 measures the available amount of energy obtained from food via cellular respiration. In this study, Waxy rice provided the highest energy value $(353.62 \mathrm{k}$. cal. $/ 100 \mathrm{~g})$, while Jasmine rice contained the lowest energy $(346.53 \mathrm{k}$. cal. $/ 100 \mathrm{~g})$, also Sakha106 rice variety contained $(352.52 \mathrm{k}$. cal./100g) and Black rice $(350.92 \mathrm{k}$. cal./100g). These data were agreed with Sompong et al. (2011) who reported that the Black rice contained energy 362.6 k. cal. /100g these result similar with Rachel et al. (2013) who showed that rice varieties (White, Brown, Black and Jasmine rice) contained energy value $(355.56,354.42,355.76$ and $357.54 \mathrm{k}$. cal. /100g) respectively.

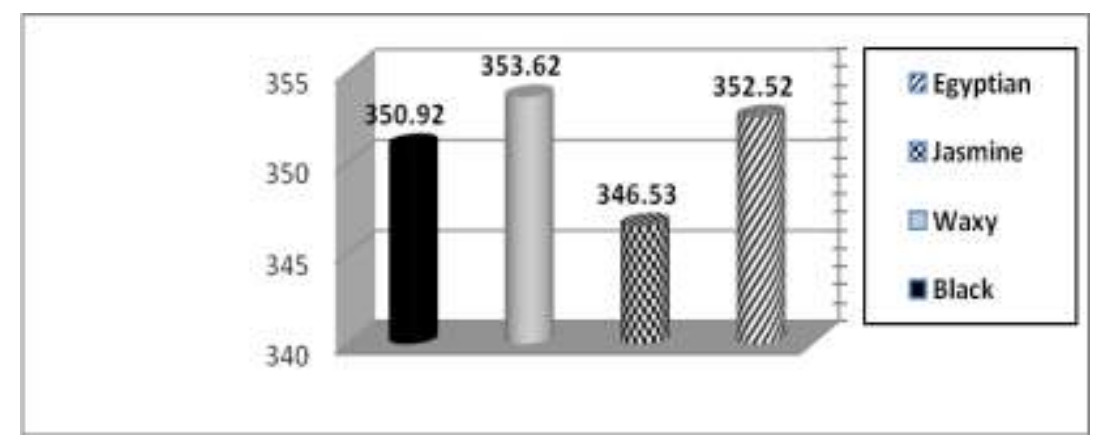

Fig. 1. Energy value of $100 \mathrm{~g}$ rice.

\section{Mineral contents}

Here is a significant differences in minerals composition $(\mathrm{mg} / 100 \mathrm{~g})$ were recorded of rice varieties, Sakha 106, Jasmine, Waxy and Black were presented in Table 5. Results showed that the varieties of Sakha106 contained the lowest values of calcium 9.67, magnesium 35.7, potassium 131.3, manganese 23.3, iron 4.21 and zinc $3.13 \mathrm{mg} / 100 \mathrm{~g}$, respectively. On the contrary, Black rice contained the highest values of the previous minerals, calcium 23.7, magnesium, 81.3, potassium 186, manganese 59.6 , iron 8.33 and zinc $6.26 \mathrm{mg} / 100 \mathrm{~g}$, respectively. On the other hand, sodium content in different rice varieties was higher in Waxy $11.6 \mathrm{mg} / 100 \mathrm{~g}$ and the lowest in Black rice which was $4.67 \mathrm{mg} / 100 \mathrm{~g}$. These result agreed with Diako et al. (2011) who reported that the white rice contained iron $5.3 \mathrm{mg} / 100$ and Jasmine $5 \mathrm{mg} / 100 \mathrm{~g}$.

TABLE 5. Minerals of some rice varieties .

\begin{tabular}{|l|c|c|c|c|}
\hline \multirow{2}{*}{$\begin{array}{l}\text { Parameters } \\
\text { mg/100g }\end{array}$} & \multicolumn{4}{|c|}{ Rice varieties } \\
\cline { 2 - 5 } & Sakha106 & Jasmine & Waxy & Black \\
\hline Calcium & $9.67^{\mathrm{d}}$ & $12.7^{\mathrm{c}}$ & $15.1^{\mathrm{b}}$ & $23.7^{\mathrm{a}}$ \\
\hline Sodium & $7.33^{\mathrm{bc}}$ & $8.66^{\mathrm{ab}}$ & $11.6^{\mathrm{a}}$ & $4.67^{\mathrm{c}}$ \\
\hline Magnesium & $35.7^{\mathrm{d}}$ & $41.6^{\mathrm{c}}$ & $56.5^{\mathrm{b}}$ & $81.3^{\mathrm{a}}$ \\
\hline Potassium & $131.3^{\mathrm{d}}$ & $142.7^{\mathrm{c}}$ & $158.3^{\mathrm{b}}$ & $186.6^{\mathrm{a}}$ \\
\hline Manganese & $23.3^{\mathrm{b}}$ & $20.2^{\mathrm{b}}$ & $22.7^{\mathrm{b}}$ & $59.6^{\mathrm{a}}$ \\
\hline Iron & $4.21^{\mathrm{c}}$ & $4.62^{\mathrm{c}}$ & $5.33^{\mathrm{b}}$ & $8.33^{\mathrm{a}}$ \\
\hline Zinc & $3.13^{\mathrm{c}}$ & $3.51^{\mathrm{c}}$ & $4.16^{\mathrm{b}}$ & $6.26^{\mathrm{a}}$ \\
\hline
\end{tabular}

Means within a column with different letters are significantly different at $(\mathrm{P} \leq 0.05)$

Egypt. J. Agron. 37, No. 1 (2015) 


\section{Antioxidants}

The results in Table 6 showed anthocyanins, total phenol, total flavonoids and antioxidant activity (DPPH\%) of the studied rice varieties. From these results it could be noticed that anthocyanins content in rice varieties Sakha106, Jasmine and Waxy not detected. On the contrary, anthocyanin content in Black rice was higher 1874.8 (mg cy-3-glc/100 g db) compared to the other varieties. Total phenol in some rice varieties ranged from $18.1(\mathrm{mg} / \mathrm{GAE} / 100 \mathrm{~g})$ in 106 to $23.6(\mathrm{mg} / \mathrm{GAE} / 100 \mathrm{~g})$ for Waxy rice, respectively.

TABLE 6. Antioxidants of some rice varieties .

\begin{tabular}{|l|c|c|c|c|}
\hline \multirow{2}{*}{ Parameters } & \multicolumn{4}{|c|}{ Rice varieties } \\
\cline { 2 - 5 } & Sakha106 & Jasmine & Waxy & Black \\
\hline Anthocyanins & $0.00^{\mathrm{b}}$ & $0.00^{\mathrm{b}}$ & $0.00^{\mathrm{b}}$ & $1874.8^{\mathrm{a}}$ \\
\hline Total phenols & $18.1^{\mathrm{d}}$ & $19.8^{\mathrm{c}}$ & $23.6^{\mathrm{b}}$ & $716.4^{\mathrm{a}}$ \\
\hline Flavonoids & $58.9^{\mathrm{d}}$ & $61.9^{\mathrm{c}}$ & $69.3^{\mathrm{b}}$ & $187.4^{\mathrm{a}}$ \\
\hline DPPH & $11.9^{\mathrm{d}}$ & $13.6^{\mathrm{c}}$ & $15.7^{\mathrm{b}}$ & $70.52^{\mathrm{a}}$ \\
\hline
\end{tabular}

Means within a column with different letters are significantly different at $(\mathrm{P} \leq 0.05)$

On the other hand, total phenols was the highest value $716.4(\mathrm{mg} / \mathrm{GAE} / 100 \mathrm{~g})$ for Black rice variety. Flavonoids values were 58.9, 61.9, 69.3 and $187.4(\mathrm{mg}$ quarstine/100g DW) for Sakha106, Jasmine, Waxy and Black rice varieties, respectively. Black rice had the highest value of DPPH (70.52\%) compared to the other varieties which were $11.9,13.6$ and $15.7 \%$, respectively.

These results agreed with Sompong et al. (2011) who reported that total anthocyanins and total phenol in Black rice were 1095.2 (mg cy-3-glc/100 g db) and $665.2(\mathrm{mg} / \mathrm{GAE} / 100 \mathrm{~g})$, respectively. while as rice pigment variety contained anthocyanins 1130 (mg cy-3-glc/100 g db). On the other hand, our results agreed with Saenkod et al. (2013) who found that total flavonoids in Black rice was 58.47 (mgquarstine/100gDW), while DPPH \% was $70.52 \%$. These may be due to Black rice contained higher amounts of total flavonoids, anthocyanins and total phenol which had antioxidants activities.

\section{Amylose content}

Amylose content is considered to be the single most important characteristic for predicting rice cooking and processing behaviors. Most consumers prefer rice with intermediate amylose content ranged between 20-25\%. Disorganized cellular structure can enhance the probabilities for high water absorption during cooking and can contribute to longer cooking time. Amylose contents determine the texture of cooked rice and rice varieties with amylose content of more than $25 \%$ absorb more water and have a fluffy texture after cooking according to Rachmat et al. (2006).

Results in Fig. 2 Showed that amylose content recorded 5.34 to 28.3 for Waxy and Sakha106 rice varieties, respectively. On the other hand, amylose value of Black rice was 12.7. These results agreed with Dipti et al. (2002) who reported that amylose content in different rice varieties in the range of 18.60 to $28.0 \%$. Also, amylose content in Jasmine rice was $20.2 \%$. While this percentage 
was $9.66 \%$ in Black rice. In addition of the Waxy rice contained $7.57 \%$ according to Osman \& Abd El-Galeel (2008).

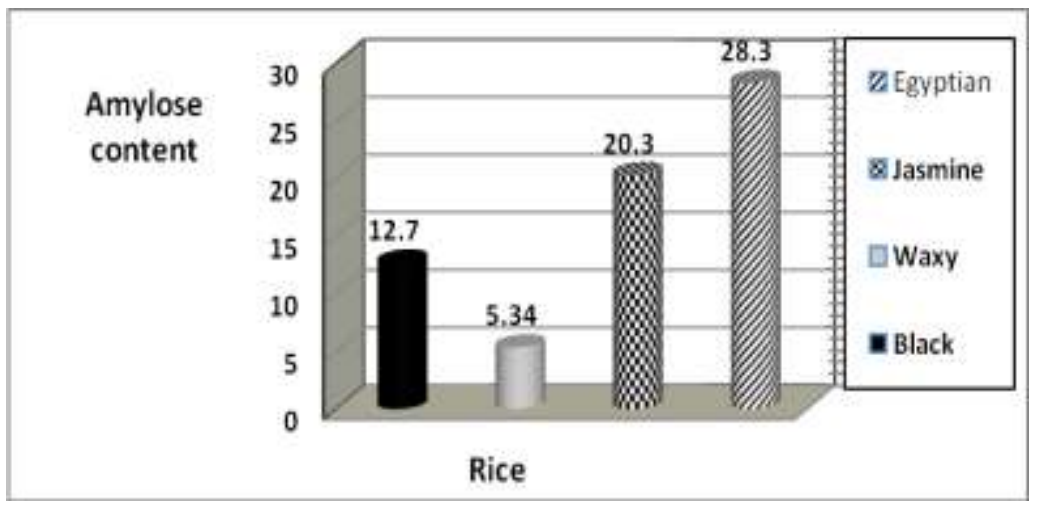

Fig.2. Amylose of some rice varieties.

\section{Cooking quality characters}

The cooking properties are very important for as rice is consumed almost immediately after cooking. Rice being a major stable food in most of the developing countries, reduced cooking time can be beneficial especially when fuel consumption is of concern (Rachel et al., 2013).

Cooking time of a rice grain is usually ascertained when an opaque center is no longer visible by $90 \%$ of the starch in the grain (Dipti et al., 2003). Results in Table 7 showed that cooking time of Black rice took the longer $27.6 \mathrm{~min}$. This may be due to the fibrous bran layer might have not yet be removed and hence it requires longer time for the starchy endosperm to cook. The minimum cooking time was found in Jasmine rice $9.33 \mathrm{~min}$. Also, Sakha106 rice variety had $14.3 \mathrm{~min}$ cooking time.

TABLE 7. Cooking quality of some rice varieties.

\begin{tabular}{|l|c|c|c|c|}
\hline \multirow{2}{*}{ Parameters } & \multicolumn{4}{|c|}{ Rice varieties } \\
\cline { 2 - 5 } & Sakha106 & Jasmine & Waxy & Black \\
\hline Cooking time $(\mathrm{mm})$ & $14.3^{\mathrm{b}}$ & $9.33^{\mathrm{d}}$ & $11.7^{\mathrm{c}}$ & $27.6^{\mathrm{a}}$ \\
\hline Water uptake ratio \% & $1.92^{\mathrm{a}}$ & $1.62^{\mathrm{b}}$ & $1.06^{\mathrm{d}}$ & $1.25^{\mathrm{c}}$ \\
\hline Gruel solid loss \% & $0.89^{\mathrm{a}}$ & $0.82^{\mathrm{b}}$ & $0.64^{\mathrm{c}}$ & $0.79^{\mathrm{b}}$ \\
\hline Elongation \% & $2.33^{\mathrm{a}}$ & $1.66 \mathrm{a}^{\mathrm{b}}$ & $0.73^{\mathrm{c}}$ & $0.92^{\mathrm{bc}}$ \\
\hline Volume expansion \% & $13.7^{\mathrm{a}}$ & $11.7^{\mathrm{b}}$ & $5.37^{\mathrm{d}}$ & $7.67^{\mathrm{c}}$ \\
\hline$(\mathrm{GT})^{*}$ & $5.24^{\mathrm{b}}$ & $4.84^{\mathrm{c}}$ & $4.17^{\mathrm{d}}$ & $5.85^{\mathrm{a}}$ \\
\hline$(\mathrm{GC})^{* *}$ & $85.7^{\mathrm{d}}$ & $87.3^{\mathrm{c}}$ & $95.1^{\mathrm{b}}$ & $92.3^{\mathrm{a}}$ \\
\hline
\end{tabular}

(Diako et al., 2011)

*Gelatinization temperature (GT) : Rating of $1-3=$ high GT (greater than $74^{\circ} \mathrm{C}$ ), Rating of $4-5=$ intermediate $\left(70-74^{\circ} \mathrm{C}\right.$ ) and Rating of $6-7=$ low GT (low $\left.70^{\circ} \mathrm{C}\right)$; **Gel consistency (GC) : Hard (27$40 \mathrm{~mm})$, medium (41-60 mm) and soft (61-100 mm).

Egypt. J. Agron. 37, No. 1 (2015) 
Water uptake ratio is an important parameter while cooking rice. If the bulk density is higher, then correspondingly water uptake ratio will also be high. This has been attributed to the compact structure of a rice variety. Water up take ratio in this study was observed to be highest for Sakha106 rice variety and the lowest 1.06 for Waxy rice variety. On the other hand, water uptake ratio was 1.25 and 1.62 for Black and Jasmine rice varieties, respectively. Amylose content might be responsible for high water uptake ratio, the result agreed with Frei \& Becker (2003) who reported that the rice with high amylose content tends to absorb more water upon cooking. It is worthy to note that high water uptake ratio affects the palatability of the cooked rice negatively.

Gruel solid loss recorded $0.64 \%$ and $0.89 \%$ in Waxy and Sakha106 rice varieties respectively, while Black and Jasmine contained $0.79 \%$ and $0.82 \%$, respectively. These observations are comparable to the report of Hirannaiah et al. (2001) who have also observed minimum gruel solid loss in Basmati rice. Rice varieties with high amylose content are more prone to leaching out into the cooking water as starch grains expand during cooking. Elongation was different by rice varieties, from the results in Table 7 it could be noticed that Sakha106 rice variety with high amylose resulted in high elongation $2.10 \%$ followed by Jasmine rice $1.66 \%$. On the other hand, Black rice contained $0.92 \%$ and Waxy rice $0.73 \%$. Elongation of rice can be influenced by both the $\mathrm{L} / \mathrm{b}$ ratio and the amylose contents Danbana et al. (2011), additionally, a positive correlation was also recorded by both amylose content and $\mathrm{L} / \mathrm{b}$ ratio in relation to elongation of rice. In this study, maximum elongation ratio was observed in Sakha106 rice variety 2.33 , followed by brown rice 1.68 .

Volume expansion (mm) in Sakha106 rice variety was the highest value $13.7 \mathrm{~mm}$ compared to the other varieties. On the contrary, the lowest value was $5.37 \mathrm{~mm}$ for Waxy rice. Jasmine and Black rice had $11.7 \mathrm{~mm}$ and $7.67 \mathrm{~mm}$ of volume expansion, respectively. The positive correlation of amylose content with water uptake, volume expansion ratio and alkali spreading value indicates that high amylose rice varieties will absorb more water at low gelatinization temperature and will produce a greater volume of cooked material (Hussain et al., 1987).

Gelatinization temperature of rice varieties were exhibited 4.17 and 5.82 for Waxy and Black rice. While Sakha106 rice varieties and Jasmine rice were 5.24 and 4.84, respectively. These results agreed with Osman \& AbdEl-Galeel (2008) who reported that Waxy rice had the highest gelatinization temperature among the other varieties. It may be due to the lowest contents of amylose. Gelatinization temperature was affected by several factors including water content of the gel, amylose content and degree of crystallinity in the amylopectin chain length. For instance, Waxy rice starch had higher gelatinization temperature and degree of gelatinization.

The results in Table 7 howed that gel consistency (mm) was 92.3 and 95.1 for Black and Waxy rice varieties, respectively. While Sakha106 rice variety and Jasmine rice was $85.7 \mathrm{~mm}$ and $87.3 \mathrm{~mm}$, respectively. Furthermore, a significant

Egypt. J. Agron. 37, No. 1 (2015) 
but low correlation value was obtained between optimum cooking time and gelatinization temperature. Significant but negative correlation values were obtained between amylose content with amylopectin and gel consistency, suggesting that rice cultivars selected for high amylose content may be invariably low in amylopectin content and gel consistency. Our results are on the parallel with the observation of Thomas et al. (2013).

\section{Conclusion}

From the results of this study it could be concluded that the new rice varieties cultivated in Egypt during two growing seasons 2012 and 2013, namely Waxy, Jasmine and Black rice are considered to be a valuable addition to the rice varieties in Egypt. Where they exhibited good quality characteristics relate to agronomy and technology. Jasmine rice variety out yielded other varieties and gave the highest values for yield and yield component characters except for 1000 grain weight which recorded the second value after both Sakha 106 and Black rice. On the other hand, Black rice gave the smallest values for yield and yield component characters except panicle weight which recorded the second value with both Waxy and Sakha 106. Jasmine rice characterized by low \% broken and $\%$ paddy which relates to reduced grain loss. Besides, Jasmine and Waxy rice had reduced cooking time which is very important in developing countries especially when fuel consumption is of concern. Black rice and its pigments has higher antioxidant activity relates to a lot of health and concerns. In addition, its high nutritional value relates to its chemical and mineral contents.

\section{Reference}

Abdelhady, S., Borello, D., Shaban, A. and Rispoli, F. (2014) Viability study of biomass power plant fired with rice straw in Egypt. The $6^{\text {th }}$. International Conference on Applied Energy - ICAE. Energy Procedia. 61, pp. 211- 215.

Adair, C.R. (1952) The McGel miller method for determining the milled quality of small samples of rice. J. Rice. 55 (2), 21-23.

Adu-Kwarteng, E., Ellis, W.O., Oduro, I. and Manful, J.T. (2003) Rice grain quality: A comparison of local varieties under study in Ghana. Food Control, 14, 507-514.

AOAC (2005) "Official Methods of Analysis of Association of Official Analytical Chemists", B, Kenesseth Helrick (Ed.) . $15^{\text {th }}$ (ed) .

Banu, B., Kabir, K.A., Begum, F. and Choudhury, N.H. (1992) Physicochemical properties of modern and local rice varieties of Bangladesh. Bangladesh Rice Journal, 3, 128-131.

Batcher, O.M., Helmintoller, K.F. and Dawson, E.H. (1956) Development and application of method for evaluating cooking and eating quality of rice. Rice Journal, 59, 4-8, 32 .

Egypt. J. Agron. 37, No. 1 (2015) 
Bhattacharya, K.R. (1979) Gelatinization temperature of rice starch and its determination. In: Proceedings of the Workshop on Chemical Aspects Of Rice Grain Quality, International Rice Research Institute. Manila, Philippines . pp. 231-249.

Codex Alimentarius Commission (1990) Proposed draft standard for rice. FAO Food Standards Programme CX/CPL/90/5. Rome, pp. 8.

Danbaba, N., Anounye, J.C., Gana, A.S., Abo, M.E. and Ukwungwu, M.N. (2011) Grain quality characteristics of rice (Oryza sativa L.): Cooking and eating quality. International Food Research Journal, 18, 629-634.

Diako, C., Manful, J.T., Johnson, P.N.T., Sakyi-Dawson, E., Bediako-Amoa, B. and Saalia, F.K. (2011) Physicochemical characterization of four commercial rice varieties in Ghana, Advance Journal of Food Science and Technology, 3(3), 196-202.

Dipti, S.S., Bari, M.N. and Kabir, K.A. (2003) Grain quality characteristics of some beru in rice varieties of Bangladesh. Pakistan Journal of Nutrition, 2, 242-245.

Dipti, S.S., Hossain, S.T., Bari, M.N. and Kabir, K.A. (2002) Physicochemical and cooking properties of some fine rice varieties. Pakistan J. Nutr. 1, 188-90.

Dorsey-Redding, C., Hurburg, C.R., Johnson, L.A. and Fox, S.R. (1991) Relationship among maize quality factors. Cereal Chem. 68, 6-12.

Elfalleh, W., Nasri, N., Marzougui, N., Thabti, I., Rabet, M. A., Yayia, Y., Lachiheb, B., Guasmi, F. and Ferchichi, A. (2009) Physico-chemical properties and DPPHABTS scavenging activity of some local pomegranate (Punicagranatum) ecotypes. $J$. Food Sci. Nutr. 60, 925-938.

FAO, (1975) Food and Agriculture Organization: Intergovernmental Group on Rice. Recommended Grading System for Rice in International Trade (Revised). FAO Rome.

Frei, M. and Becker, K. (2003) Studies on the in vitro starch digestibility and glycemic index of six different indigenous rice cultivars from the Philippines, Journal of Food Chemistry, 83, 395-400.

Giusti, M.M. and Wrolstad, R.E. (2005) "Characterization and Measurement of Anthocyanin's by UV-Visible Spectroscopy" . In R.E. Worsted, T.E. A cree, E.A. Decker, M.H .Pinner, D.S. Reid, S.J. Schwartz, C.F. Shoemaker (Ed.) . pp. 19-31.

Hawk, P.O., Oser, B.L. and Sum, M.W. (1949) Practical physiological chemistry. J. Nutri. 12, 962.

Hirannaiah, B. V., Bhashyam, M. K. and Ali, S. Z. (2001) An improved cooking quality test for Basmati rice. Journal of Food Science and Technology, 38, 116-119.

Hosseinian, F.S., Li, W. and Beta, T. (2008) Measurement of anthocyanins and other phytochemicals in purple wheat. Food Chemistry. 109, 916-924.

Hussain, A.A., Muarya, D.M. and Vaish, C.P. (1987) Studies on quality status of indigenous upland rice (Oryza sativa), Indian J. Genet. 47, 145-152.

Egypt. J. Agron. 37, No. 1 (2015) 
Juliano, B. O., Perez, C. M., Blakeney, A. B., Castillo, D.T., Kongseree, N., Laignelet, B., Lapis, E.T., Murty, V. V. S. and Webb, B. D. (1981) International cooperative testing on the amylase content of milled rice. Starch, 33, 157-162.

Little, R. R., Hilder, G. B. and Dawson, E. H. (1958) Differential effect of dilute alkali on 25 varieties of milled white rice. Cereal Chemistry, 35, 111-126.

Mahajan, S. and Kaur, S. (2014) Quality analysis of Indian Basmati rice grains using top-hat transformation. Inter. J. Computer Applications, 94, $42-47$.

Majzoobi, M. and Farahnaky, A. (2008) The physiochemical properties of starch components of six Iranian rice cultivars. Iran Agricultural Research, 27, 113-122.

Nasri, N., Tlili, N., Ellfalleh, W., Emna, C., Ferchichi, A., Khaldi, A. and Saida, T. (2011) Chemical compounds from Phoenician juniper berries (Juniperusphoenicea). Natural Product Research, 25, 1733-1742.

Okonogi, S., Duangrat, C., Anuchpreeda, S., Tachakittirungrod, S. and Chowwanapoonpohn, S. (2007) Comparison of antioxidant capacities and cytotoxicities of certain fruit peels. Food Chemistry, 103, 839-846.

Osman, M.F. and Abd El-Galeel, M.A. (2008) Physical, chemical, thermal and technological properties of some Egyptian rice varieties. J. Agric. Sci. Mansoura Univ. 33(8), 5893-5909.

Rachel, T., Wan-Nadiah, W.A. and Rajeev, B. (2013) Physiochemical properties, proximate composition, and cooking qualities of locally grown and imported rice varieties marketed in Penang, Malaysia. International Food Research Journal, 20(3),1345-1351.

Rachmat, R., Thahir, R. and Gummert, M. (2006) The empirical relationship between price and quality of rice at market level in West Java. Indonesian J. Agric. Sci. 7, 27-33.

Rita, B. and Sarawgi, A.K. (2008) Agro-morphological and quality characterization of badshahbhog group from aromatic rice germ plasm of Chhattisgarh. Bangladesh Journal of Agriculture Research, 33, 479-492.

Sadhukhan, R. N. and Chattopadhyay, P. (2000) Variability and character association between yield attributes and grain quality in aromatic rice. J. Interacademicia, 4(4), 494-497.

Saenkod, C., Liu, Z., Huang, J. and Gong, Y. (2013) Anti-oxidative biochemical properties of extracts from some Chinese and Thai rice varieties. African Journal of Food Science, 7(9), 300-305.

Siddiqui, S.U., Kumamaru, T. and Satoh, H. (2007) Pakistan rice genetic resources-I: grain morphological diversity and its distribution. Pak. J. Bot. 39, 841-848.

Singh, N., Kaur, L., Singh, S.N. and Sekhon, K.S. (2005) Physicochemical, cooking and textural properties of milled rice from different Indian rice cultivars. Food Chemistry, 89, 253-259.

Egypt. J. Agron. 37, No. 1 (2015) 
Singh, N., Sodhi, N.S., Kaur, M. and Saxena, S.K. (2003) Physico-chemical, morphological, thermal, cooking and textural properties of chalky and translucent rice kernels. Food Chemistry, 82, 433-439.

Sompong, R., Siebenhandl-Ehn, S., Linsberger-Martin, G. and Berghofer, E. (2011) Physicochemical and antioxidative properties of red and black rice varieties from Thailand. China and Srilanka Food Chemistry, 124, 132-140.

Thomas, R., Wan-Nadiah, W. A. and Bhat, R. (2013) Physiochemical properties, proximate composition, and cooking qualities of locally grown and imported rice varieties marketed in Penang, Malaysia. IFRJ, 20, 1345- 1351.

Warda (1995) West Africa Rice Development Association. Grain quality laboratory database. WARDA, Bouake, Mali.

Yodmanee, S., Karrila, T.T. and Pakdeechanuan, P. (2011) Physical, chemical and antioxidant properties of pigmented rice. Inter Food Res. J. 18, 901-906.

(Received 4/5/2015; accepted 25/6/2015) 


\section{دراسة الصفات المحصولية و خصائص الجودة التكنولوجية لبعض أصناف الأرز المصرية الصنية

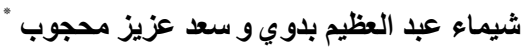

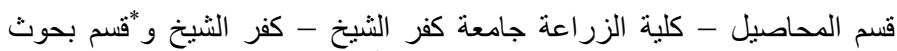

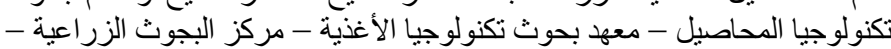

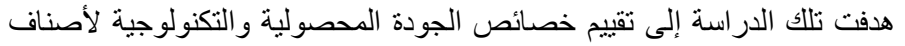

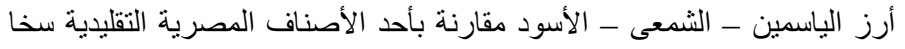

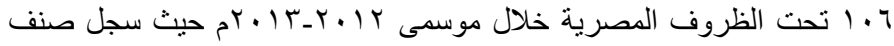

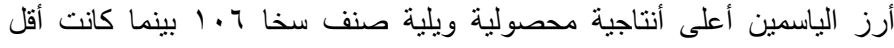

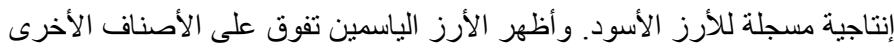

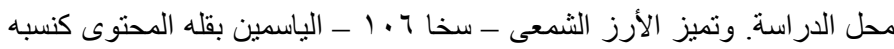

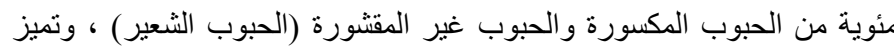

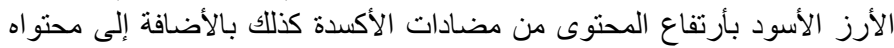

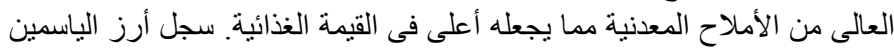

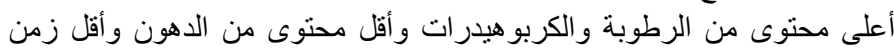

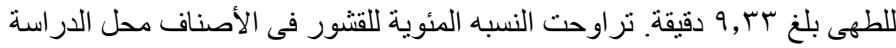

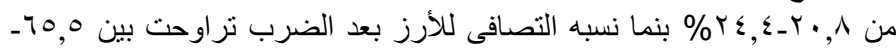




الأرز الأسود على أعلى نسبه من الأنسوسيانين و الفلافونيدات الأنى الكلية. 
